\author{
Critical Care Medicine \\ Issue: Volume 25(11), November 1997, pp 1868-1873 \\ Copyright: @ Williams \& Wilkins 1997. All Rights Reserved. \\ Publication Type: [Laboratory Investigations] \\ ISSN: 0090-3493 \\ Accession: 00003246-199711000-00027
}

[Laboratory Investigations]

\title{
Improved oxygenation by nitric oxide is enhanced by prior lung reaeration with surfactant, rather than positive end-expiratory pressure, in lung-lavaged rabbits
}

Gommers, Diederik MD; Hartog, Arthur MSc; van't Veen, Annemarie MSc; Lachmann, Burkhard MD, PhD

\section{Author Information}

From the Department of Anesthesiology, Erasmus University Rotterdam, Rotterdam, The Netherlands. Supported, in part, by the International Foundation for Clinically Oriented Research. Equipment was made available by Siemens-Elema AB, Soina, Sweden.

Address requests for reprints to: Dr. Burkhard Lachmann, Department of Anesthesiology (Room Ee 2393), Erasmus University Rotterdam, P.O. Box 1738, 3000 DR Rotterdam, The Netherlands.

\begin{abstract}
Objectives: The inhalation of nitric oxide increases oxygenation by improving the ventilation/perfusion ratios in neonates with respiratory distress syndrome and those ratios in adults with acute respiratory distress syndrome. There is evidence that inhaled nitric oxide is ineffective when the lung remains atelectatic and poorly inflated. This study aimed to enhance nitric oxide delivery by improving lung aeration by means of exogenous surfactant or by increasing positive end-expiratory pressure.
\end{abstract}

Design: Experimental, comparative study.

Setting: Research laboratory of a large university.

Subjects: Twenty-eight adult New Zealand white rabbits, weighing $2.7+/-0.3 \mathrm{~kg}$.

Interventions: Lung injury was induced by repeated wholelung lavage with saline. The animals were mechanically ventilated with a tidal volume of $10 \mathrm{~mL} / \mathrm{kg}$, an FIO sub 2 of 1.0 , and a positive endexpiratory pressure of $6 \mathrm{~cm} \mathrm{H}_{2} \mathrm{O}$. Forty-five minutes after the last lavage, the animals were randomly assigned to five groups. In two groups, lung aeration was first increased either by instillation of a low dose of exogenous surfactant $(25 \mathrm{mg} / \mathrm{kg}$ ) or by increasing the positive end-expiratory pressure to $10 \mathrm{~cm} \mathrm{H}_{2} \mathrm{O}$, before inhalation of nitric oxide was started. In each of these animals, five different nitric oxide concentrations ( 4 to 20 parts per million) were inhaled for 30 mins, followed by a 30-min washout period. The other three groups served as controls and received only one treatment protocol: nitric oxide (4 to 20 parts per million), or surfactant $\left(25 \mathrm{mg} / \mathrm{kg}\right.$ ), or positive end-expiratory pressure $\left(10 \mathrm{~cm} \mathrm{H}_{2} \mathrm{O}\right.$ ).

Measurements and Main Results: Before and after lavage, blood gases and lung mechanics were measured every 30 mins. Both strategies to increase lung aeration improved $\mathrm{PaO}_{2}$ values from $61+/-$ 13 torr $(8.1+/-1.7 \mathrm{kPa})$ to 200 to 300 torr (26.6 to $39.9 \mathrm{kPa})$ in 30 mins. After inhalation of nitric oxide, additional increases of oxygenation were seen only in the animals that received a low dose $(25 \mathrm{mg} / \mathrm{kg})$ of 
7/26/2016 Ovid: Improved oxygenation by nitric oxide is enhanced by prior lung reaeration with surfactant, rather than positive end-expiratory pressure, in lung-...

surfactant. The control group that inhaled nitric oxide showed no significant change in oxygenation, and four of the six animals did not survive the observation period. In the two groups in which positive endexpiratory pressure was increased to $10 \mathrm{~cm} \mathrm{H}_{2} \mathrm{O}$, half of the animals developed a pneumothorax during the observation period.

Conclusion: These data indicate that inhaled nitric oxide is able to improve arterial oxygenation after alveolar recruitment by means of a low dose of exogenous surfactant, and not by increase of positive end-expiratory pressure from 6 to $10 \mathrm{~cm} \mathrm{H}_{2} \mathrm{O}$, in lunglavaged rabbits. (Crit Care Med 1997; 25:18681873)

Key Words: respiratory distress syndrome; pulmonary surfactants; nitric oxide; disease models, animal; lung; pulmonary gas exchange; respiratory mechanics; critical illness

In 1987, nitric oxide, the endothelium-derived relaxing factor synthesized from L-arginine by the enzyme nitric oxide synthase, was identified as an important endogenous vasodilator [1]. Inhalation of exogenous nitric oxide has been shown to be beneficial with respect to reducing pulmonary hypertension and improving arterial oxygenation in neonates with respiratory distress syndrome (RDS) and in adults with acute respiratory distress syndrome (ARDS) [2-7]. It is assumed that inhaled nitric oxide rapidly diffuses across the alveolar barrier to vascular smooth muscle, causing relaxation of the vascular smooth muscle, which, in turn, causes vasodilation of the pulmonary vessels [8]. Excess nitric oxide that reaches the bloodstream binds rapidly and avidly to hemoglobin; this binding to hemoglobin eliminates the availability of nitric oxide for causing systemic vasodilation [8].

Recently, Kinsella and Abman [9] reported that the inhalation of nitric oxide resulted in a limited success in improving blood gases, especially in newborns with reduced lung compliance. It has been suggested that the reduced lung volume probably contributes to the decreased efficacy of inhaled nitric oxide by decreased effective delivery of nitric oxide to the pulmonary vasculature $[9,10]$. Therefore, it could be expected that after reaeration of atelectatic lung regions by either exogenous surfactant or by increasing the positive endexpiratory pressure, the effect of inhaled nitric oxide on oxygenation would be enhanced, as long as a ventilation/perfusion mismatch is present.

To test this hypothesis, a study was designed in which we investigated the effects of inhaled nitric oxide, combined either with a low dose of exogenous surfactant or increased positive end-expiratory pressure, on blood gases in surfactant-depleted rabbits.

\section{MATERIALS AND METHODS}


7/26/2016 Ovid: Improved oxygenation by nitric oxide is enhanced by prior lung reaeration with surfactant, rather than positive end-expiratory pressure, in lung-...

This study was approved by the local Animal Committee of Erasmus University Rotterdam. Care and handling of the animals were in accord with the European Community guidelines (86/609/EEG). A total of 28 adult New Zealand white rabbits (IFFA-Credo, Brussels, Belgium), with a mean body weight of $2.7+/-$ $0.3 \mathrm{~kg}$, were anesthetized with intravenous sodium pentobarbital $(50 \mathrm{mg} / \mathrm{kg})$ via an auricular vein. Tracheostomy was performed, and an uncuffed endotracheal tube was introduced into the trachea. Mechanical ventilation with an $\mathrm{FIO}_{2}$ of 1.0 was performed using a ventilator (Servo 300, Siemens-Elema $A B$, Solna, Sweden), with volume-controlled mode, tidal volume of $10 \mathrm{~mL} / \mathrm{kg}$, positive end-expiratory pressure of $2 \mathrm{~cm} \mathrm{H}_{2} \mathrm{O}$, frequency of $30 \mathrm{breaths} / \mathrm{min}$, inspiration time of $25 \%$, and a pause time of $10 \%$. An infusion of $2.5 \%$ glucose was continuously administered via the auricular vein as a maintenance fluid (5 $\mathrm{mL} / \mathrm{kg} / \mathrm{hr})$. Anesthesia was maintained with intermittent injection of pentobarbital sodium $(5 \mathrm{mg} / \mathrm{kg} / \mathrm{hr} \mathrm{iv})$; muscle paralysis was achieved with pancuronium bromide $(0.1 \mathrm{mg} / \mathrm{kg} / \mathrm{hr} \mathrm{im})$. A femoral artery was cannulated with a polyethylene catheter for continuous blood pressure measurements and for intermittent blood sampling. Arterial samples were analyzed for blood gases, hemoglobin, and methemoglobin saturation using conventional methods (ABL-505 and Osm-3, Radiometer, Copenhagen, Denmark). Core temperature was measured using an esophageal thermistor (Elektrolaboratoriet, Copenhagen, Denmark) and maintained at $99+/-1$ [degree sign]F $(37+/-0.5$ [degree sign] C) by a heating pad.

In all animals, respiratory insufficiency was induced by repeated wholelung lavage ( $30 \mathrm{~mL} / \mathrm{kg})$, according to the method of Lachmann et al [11]. After the first lavage, positive end-expiratory pressure was increased to $6 \mathrm{~cm} \mathrm{H}_{2} \mathrm{O}$ (other ventilator settings were not changed) and whole-lung lavage was repeated until $\mathrm{PaO}_{2}$ was $<80$ torr $(<10.6 \mathrm{kPa}$ ). After the last lavage, all animals were ventilated for $45 \mathrm{mins}$, and after blood gases were measured, the animals were randomly divided into five groups. The first group $(n=6)$, received a low dose of surfactant $(25 \mathrm{mg} / \mathrm{kg})$ intratracheally which, 30 mins later, was followed by inhalation of nitric oxide. Five different concentrations of nitric oxide $(4,8,10,16$, and 20 parts per million [ppm]) were each inhaled for 30 mins. The sequence of the five nitric oxide concentrations was randomized for each animal. After each nitric oxide inhalation for $30 \mathrm{mins}$, blood gases were measured and nitric oxide was turned off for 30 mins to get a new baseline blood gas value. In another group $(n=6)$, positive end-expiratory pressure was increased from 6 to $10 \mathrm{~cm} \mathrm{H}_{2} \mathrm{O}$, and, after 30 mins, inhaled nitric oxide was given in the same way as described above. The other three groups served as controls and received the following treatments: a) nitric oxide alone in the same way as described above $(n=6)$; b) $25 \mathrm{mg} / \mathrm{kg}$ of surfactant alone $(n=5)$; or c) a positive end-expiratory pressure of $10 \mathrm{~cm} \mathrm{H}_{2} \mathrm{O}$ alone $(n=5)$.

The surfactant used in this study was a freeze-dried natural surfactant isolated from minced pig lungs, as previously described [12]. For instillation of the surfactant, animals were disconnected from the ventilator and received the surfactant suspension $(25 \mathrm{mg} / \mathrm{mL})$ directly into the endotracheal tube via a syringe. The animals were then immediately reconnected to the ventilator (ventilator settings were not changed).

A new prototype ventilator was used (Siemens-Elema AB, Solna, Sweden), with a built-in, computerized, nitric oxide delivery system, consisting of an additional digital-controlled nitric oxide valve. An on-line electrochemical sensor was used to continuously measure expiratory nitric oxide and nitric dioxide concentrations. This system has been used in adult patients with ARDS and has proven to be reliable [5].

Data were collected at the following times: before lavage; 5 and 45 mins after the lavage procedure; and every 30 mins for $5.5 \mathrm{hrs}$. In the control group that received nitric oxide only, data were collected for only 5 hrs because there was no lung aeration improvement procedure. At each data collection point, $\mathrm{PaO}_{2}$, $\mathrm{PaCO}_{2}$, methemoglobin, blood pressures, peak airway pressure, positive end-expiratory pressure, and mean airway pressures were measured. 
7/26/2016 Ovid: Improved oxygenation by nitric oxide is enhanced by prior lung reaeration with surfactant, rather than positive end-expiratory pressure, in lung-...

Statistical analysis of the data was performed using the SAS statistical package (SAS Users Guide, 1990, SAS Institute, Cary NC). Between-group differences for $\mathrm{PaO}_{2}, \mathrm{PaCO}_{2}$, mean arterial pressure, mean airway pressure, and peak pressure were tested with an analysis of variance for repeated time measurements using the general linear models procedure. In addition, a paired t-test was performed to test the effect of each nitric oxide concentration on $\mathrm{PaO}_{2}$ within one group. When nitric oxide was switched on for 30 mins, the mean $\mathrm{PaO}_{2}$ value was compared with the mean baseline $\mathrm{PaO}_{2}$ value that was defined as the mean $\mathrm{PaO}_{2}$ of both washout periods before and after nitric oxide was switched on. Differences were accepted as significant at $p<$ or=to .05. For the nitric oxide effects, no adjustments were made for multiple comparisons.

\section{RESULTS}

In a preliminary study (unpublished observations), it was found that giving a dose of $25 \mathrm{mg}$ of surfactant per $\mathrm{kg}$ of body weight or increasing the positive end-expiratory pressure level from 6 to $10 \mathrm{~cm} \mathrm{H}_{2} \mathrm{O}$ after the lavage procedure led to an improvement of arterial oxygenation to $50 \%$ of the prelavage $\mathrm{PaO}_{2}$ values $\left(\mathrm{PaO}_{2} / \mathrm{FIO}_{2}\right.$ from 60 to 80 torr [8.0 to $10.7 \mathrm{kPa}$ ] to 200 to 300 torr [26.7 to $40.0 \mathrm{kPa}$ ]).

In the two groups receiving exogenous surfactant $(25 \mathrm{mg} / \mathrm{kg})$, mean $\mathrm{PaO}$ sub 2 values increased from $58+/$ 11 torr $(7.7+/-1.5 \mathrm{kPa})$ to $283+/-64$ torr $(37.6+/-8.5 \mathrm{kPa})$ in 30 mins (Figure 1). After additional nitric oxide inhalations, $\mathrm{PaO}_{2}$ further increased and decreased when nitric oxide was switched off. The mean $\mathrm{PaO}_{2}$ values of the group receiving the combination of surfactant and nitric oxide were significantly higher compared with the group that received surfactant only (Figure 1). In this last group, $\mathrm{PaO}_{2}$ was maximal at 30 mins after surfactant instillation and decreased over time (Figure 1). $\mathrm{PaCO}_{2}$ and peak airway pressure decreased directly after surfactant instillation but slowly increased during the following observation period (Table 1 and Table 3).

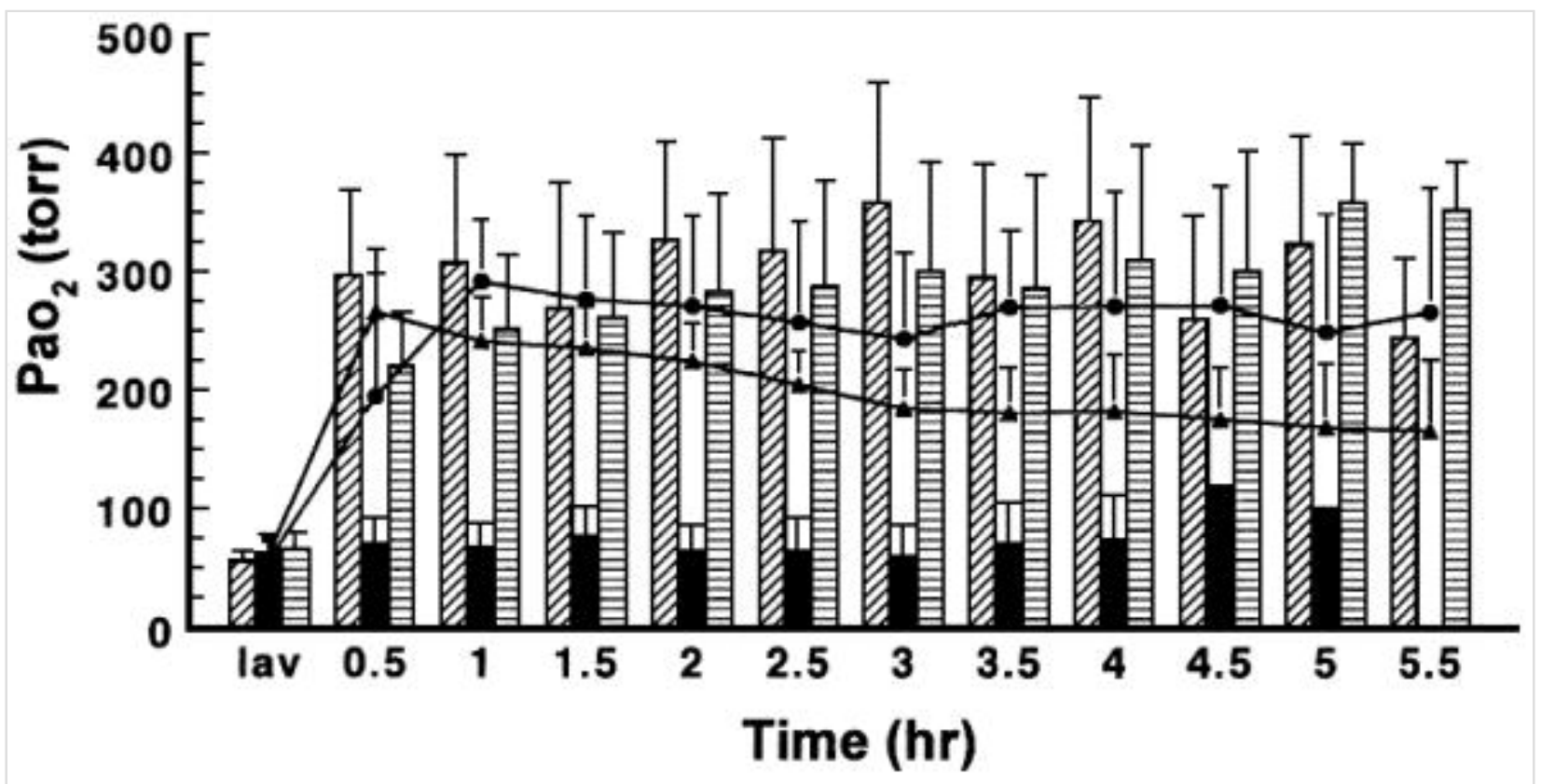

Figure 1. Mean change in $\mathrm{PaO}_{2}$ values (+/- SD) for all five groups. Diagonal-striped bar, animals $(n=6)$ treated with a low dose of exogenous surfactant $(25 \mathrm{mg} / \mathrm{kg})$ and inhaled nitric oxide; horizontal-striped bar, animals $(\mathrm{n}=$ 6) treated with a positive end-expiratory pressure of $10 \mathrm{~cm} \mathrm{H}_{2} \mathrm{O}$ and inhaled nitric oxide; solid bar, animals ( $\mathrm{n}=6$ ) treated with inhaled nitric oxide alone. The solid lines indicate two control groups: triangles, animals $(n=5)$ treated with a low dose of exogenous surfactant $(25 \mathrm{mg} / \mathrm{kg})$ alone; circles, animals $(\mathrm{n}=5)$ treated with a positive end-expiratory pressure of $10 \mathrm{~cm} \mathrm{H}_{2} \mathrm{O}$. lav, 45 mins after the last lavage. To convert torr to $\mathrm{kPa}$, multiply the value by 0.1333 . 
7/26/2016 Ovid: Improved oxygenation by nitric oxide is enhanced by prior lung reaeration with surfactant, rather than positive end-expiratory pressure, in lung-...

\begin{tabular}{|c|c|c|c|c|c|c|c|c|c|}
\hline \multirow[b]{2}{*}{ Variable } & \multirow[b]{2}{*}{ Prelavage } & \multirow[b]{2}{*}{ Group } & \multirow[b]{2}{*}{ Lavage } & \multicolumn{6}{|c|}{ Time (min) } \\
\hline & & & & 30 & 60 & 90 & 120 & 150 & 180 \\
\hline \multirow{5}{*}{$\begin{array}{l}\mathrm{PaCO}_{2} \\
\text { (torr) }\end{array}$} & $36=3$ & Surf + NO & $58 \pm 10$ & $46 \pm 6$ & $45 \pm 3$ & $48=6$ & $48 \pm 7$ & $48 \pm 7$ & $48=8$ \\
\hline & $37=3$ & $\mathrm{PEEP}+\mathrm{NO}$ & $57 \pm 7$ & $54 \pm 6$ & $57 \pm 6$ & $58=4$ & $60 \pm 5$ & $58 \pm 5$ & $57=7$ \\
\hline & $34=5$ & NO & $52 \pm 6$ & $51 \pm 10$ & $54 \pm 12$ & $55=14$ & $57 \pm 13$ & $60 \pm 14$ & $60 \pm 18^{b}$ \\
\hline & $32 \pm 6$ & Surf & $55 \pm 6$ & $48 \pm 3$ & $49 \pm 6$ & $49 \pm 2$ & $48 \pm 3$ & $50 \pm 3$ & $50=5$ \\
\hline & $32=4$ & PEEP & $46 \pm 4$ & $45 \pm 4$ & $46+7$ & $47 \div 3$ & $48+4$ & $49 \pm 6$ & $53 \div 3^{r}$ \\
\hline \multirow{5}{*}{$\begin{array}{l}\mathrm{MAP} \\
\qquad(\mathrm{mm} \mathrm{Hg})\end{array}$} & $97 \pm 9$ & Surf + NO & $90 \pm 10$ & $82=11$ & $81 \pm 7$ & $81=11$ & $81=7$ & $83 \pm 7$ & $87=9$ \\
\hline & $105=11$ & $\mathrm{PEEP}+\mathrm{NO}$ & $101 \pm 14$ & $87=9$ & $86 \pm 12$ & $89=13$ & $86=14$ & $82 \pm 12$ & $78=10$ \\
\hline & $99=8$ & NO & $88 \pm 13$ & $82=17$ & $83 \pm 14$ & $85=10$ & $88=10$ & $89 \neq 15$ & $74=18$ \\
\hline & $108=7$ & Surf & $91 \pm 9$ & $90=14$ & $89 \pm 13$ & $90=14$ & $89=12$ & $89 \pm 14$ & $94=13$ \\
\hline & $104=11$ & PEEP & $94 \pm 10$ & $89=5$ & $91 \pm 11$ & $89=5$ & $85 \pm 5$ & $91 \pm 9$ & $90=9^{\prime}$ \\
\hline \multirow{5}{*}{$\begin{array}{l}\text { Pmean } \\
\qquad\left(\mathrm{cm} \mathrm{H}_{2} \mathrm{O}\right)\end{array}$} & $5=3$ & Surf + NO & $11 \pm 1$ & $10=1$ & $10 \pm 1$ & $10=1$ & $10 \pm 1$ & $10 \pm 1$ & $10=1$ \\
\hline & $6=1$ & $\mathrm{PEEP}+\mathrm{NO}$ & $12 \pm 1$ & $17=2$ & $17 \pm 2$ & $17 \pm 2$ & $17 \pm 2$ & $17 \pm 2$ & $17=2$ \\
\hline & $5 \pm 0$ & NO & $11 \pm 1$ & $12=1$ & $12 \pm 1$ & $12 \pm 1$ & $12 \pm 1$ & $12 \pm 1$ & $12 \pm 1$ \\
\hline & $5=0$ & Surf & $11 \pm 1$ & $10+1$ & $11 \pm 1$ & $11=1$ & $11 \pm 1$ & $11 \pm 1$ & $11=1$ \\
\hline & $6 \pm 1$ & PEEP & $12 \pm 2$ & $16+1$ & $16+1$ & $16 \pm 1$ & $16 \pm 1$ & $16 \pm 1$ & $16=1$ \\
\hline \multirow{5}{*}{$\begin{array}{l}\text { Ppeak } \\
\qquad\left(\mathrm{cm} \mathrm{H}_{2} \mathrm{O} \text { ) }\right.\end{array}$} & $11 \pm 1$ & Surf + NO & $24 \pm 2$ & $22+2$ & $22 \pm 2$ & $22 \pm 3$ & $23 \pm 3$ & $23 \pm 3$ & $23 \pm 3$ \\
\hline & $13 * 2$ & $\mathrm{PEEP}+\mathrm{NO}$ & $24 \pm 2$ & $28=1$ & $27 \pm 1$ & $27=1$ & $28 \pm 1$ & $28 \pm 1$ & $28=1$ \\
\hline & $13=2$ & NO & $25 \neq 1$ & $26=2$ & $26 \pm 2$ & $28=2$ & $28 \pm 1$ & $29 \pm 2$ & $29=2$ \\
\hline & $12=1$ & Surf & $25 \pm 2$ & $24=2$ & $24 \pm 2$ & $24=2$ & $25=2$ & $25 \pm 3$ & $25=3$ \\
\hline & $12=1$ & PEEP & $26 \pm 2$ & $29=2$ & $30 \pm 2$ & $29=1$ & $29 \pm 1$ & $30 \pm 1$ & $31=1$ \\
\hline
\end{tabular}

Surf + NO, animals treated with surfactant and nitric oxide; PEEP + NO, animals treated with a positive end-expiratory pressur treated with surfactant only; PEEP, animals treated with positive end-expiratory pressure of $10 \mathrm{~cm} \mathrm{H}_{2} \mathrm{O}$ only; - , not measured.

To convert torr to $\mathrm{kPa}$, multiply the value by 0.1333 .

Three pneumothoraces; "death of one animal; "one pneumothorax.

Table 1. $\mathrm{PaCO}_{2}$, mean arterial pressure (MAP), mean airway pressure (Pmean), and peak inspiratory pressure (Ppeak) in the five

Time $(\min )$

\begin{tabular}{|c|c|c|c|c|}
\hline 210 & 240 & 270 & 300 & 330 \\
\hline $48 \pm 9$ & $49 \pm 10$ & $50 \pm 11$ & $50 \pm 11$ & $50 \pm 10$ \\
\hline $55 \pm 6$ & $55 \pm 4$ & $55 \pm 5^{a}$ & $53 \pm 2$ & $51 \pm 1$ \\
\hline $55 \pm 19^{b}$ & $53 \pm 17^{b}$ & $54 \pm 2^{b}$ & $54 \pm 2$ & - \\
\hline $51 \pm 5$ & $51 \pm 6$ & $51 \pm 6$ & $52 \pm 7$ & $52 \pm 6$ \\
\hline $53 \pm 3$ & $55 \pm 3^{c}$ & $54 \pm 2$ & $57 \pm 1^{c}$ & $54 \pm 4$ \\
\hline $88 \pm 6$ & $90 \pm 10$ & $89 \pm 9$ & $91 \pm 10$ & $89 \pm 9$ \\
\hline $78 \pm 11$ & $78 \pm 9$ & $77 \pm 8^{a}$ & $76 \pm 6$ & $70 \pm 15$ \\
\hline $77 \pm 23^{b}$ & $82 \pm 9^{b}$ & $87 \pm 3^{b}$ & $85 \pm 4$ & - \\
\hline $88 \pm 13$ & $91 \pm 17$ & $86 \pm 15$ & $83 \pm 25$ & $80 \pm 19$ \\
\hline $88 \pm 1$ & $85 \pm 5^{c}$ & $84 \pm 5$ & $90 \pm 4^{c}$ & $76 \pm 16$ \\
\hline $10 \pm 1$ & $10 \pm 1$ & $11 \pm 1$ & $11 \pm 1$ & $11 \pm 1$ \\
\hline $17 \pm 2$ & $17 \pm 2$ & $17 \pm 2^{a}$ & $18 \pm 2$ & $18 \pm 2$ \\
\hline $12 \pm 1^{b}$ & $12 \pm 2^{b}$ & $12 \pm 2^{b}$ & $12 \pm 2$ & - \\
\hline $11 \pm 1$ & $11 \pm 1$ & $11 \pm 1$ & $11 \pm 1$ & $11 \pm 1$ \\
\hline $16 \pm 1$ & $16 \pm 2$ & $16 \pm 2$ & $15 \pm 1^{c}$ & $15 \pm 1$ \\
\hline $23 \pm 3$ & $23 \pm 2$ & $23 \pm 2$ & $23 \pm 2$ & $24 \pm 2$ \\
\hline $28 \pm 1$ & $28 \pm 2$ & $28 \pm 1^{a}$ & $27 \pm 1$ & $27 \pm 1$ \\
\hline $30 \pm 1^{b}$ & $30 \pm 1^{b}$ & $30 \pm 1^{b}$ & $30 \pm 1$ & - \\
\hline $25 \pm 3$ & $25 \pm 3$ & $25 \pm 3$ & $25 \pm 3$ & $25 \pm 3$ \\
\hline $31 \pm 1$ & $32 \pm 1^{c}$ & $32 \pm 1$ & $32 \pm 1^{c}$ & $31 \pm 1$ \\
\hline
\end{tabular}

of $10 \mathrm{~cm} \mathrm{H}_{2} \mathrm{O}$ and nitric oxide; $\mathrm{NO}$, animals treated with nitric oxide only; Surf, animals Table 3. Table 1 study groups (mean +/- SD) 
7/26/2016 Ovid: Improved oxygenation by nitric oxide is enhanced by prior lung reaeration with surfactant, rather than positive end-expiratory pressure, in lung-...

In the two groups in which positive end-expiratory pressure was increased from 6 to $10 \mathrm{~cm} \mathrm{H}_{2} \mathrm{O}$, mean $\mathrm{PaO}_{2}$ values increased from $62+/-15$ torr $(8.2+/-2.0 \mathrm{kPa})$ to $239+/-48$ torr $(31.8+/-6.4 \mathrm{kPa})$ in 30 mins (Figure 1). After nitric oxide was inhaled by one of these groups, no significant difference in mean $\mathrm{PaO}_{2}$ values was seen compared with the group that received a positive end-expiratory pressure of $10 \mathrm{~cm} \mathrm{H}_{2} \mathrm{O}$ only (Figure 1). In the group receiving the combination of a positive end-expiratory pressure of $10 \mathrm{~cm} \mathrm{H}_{2} \mathrm{O}$ and inhaled nitric oxide, mean $\mathrm{PaO}_{2}$ values improved over time but did not decrease when nitric oxide was switched off. Peak airway pressure and mean airway pressure were significantly higher in the two groups that received a positive end-expiratory pressure of $10 \mathrm{~cm} \mathrm{H}_{2} \mathrm{O}$, as compared with the two surfactant-treated groups. Half of the animals in both positive end-expiratory pressure groups developed a pneumothorax during the observation period (Table 1 and Table 3).

There was no change in mean $\mathrm{PaO}_{2}$ values after inhalation of nitric oxide in the group that received nitric oxide only (Figure 1). In this group, PaCO sub 2 and peak airway pressure increased over time and four of six animals did not survive the observation period (Table 1 and Table 3). For the three groups that received nitric oxide, the mean changes of $\mathrm{PaO}_{2}$ per nitric oxide concentration are given in Figure 2. The $\mathrm{PaO}_{2}$ response was higher in the group receiving the combination of surfactant and nitric oxide for each nitric oxide concentration but there was no difference in $\mathrm{PaO}_{2}$ response to the different nitric oxide concentrations used (Figure 2). Nonresponse (defined as an increase in $\mathrm{PaO}_{2}$ of $<10 \%$ above the baseline $\mathrm{PaO}_{2}$ value) was $27 \%$ in the group receiving surfactant and nitric oxide, $93 \%$ in the group receiving positive endexpiratory pressure and nitric oxide, and $58 \%$ in the group receiving nitric oxide only.

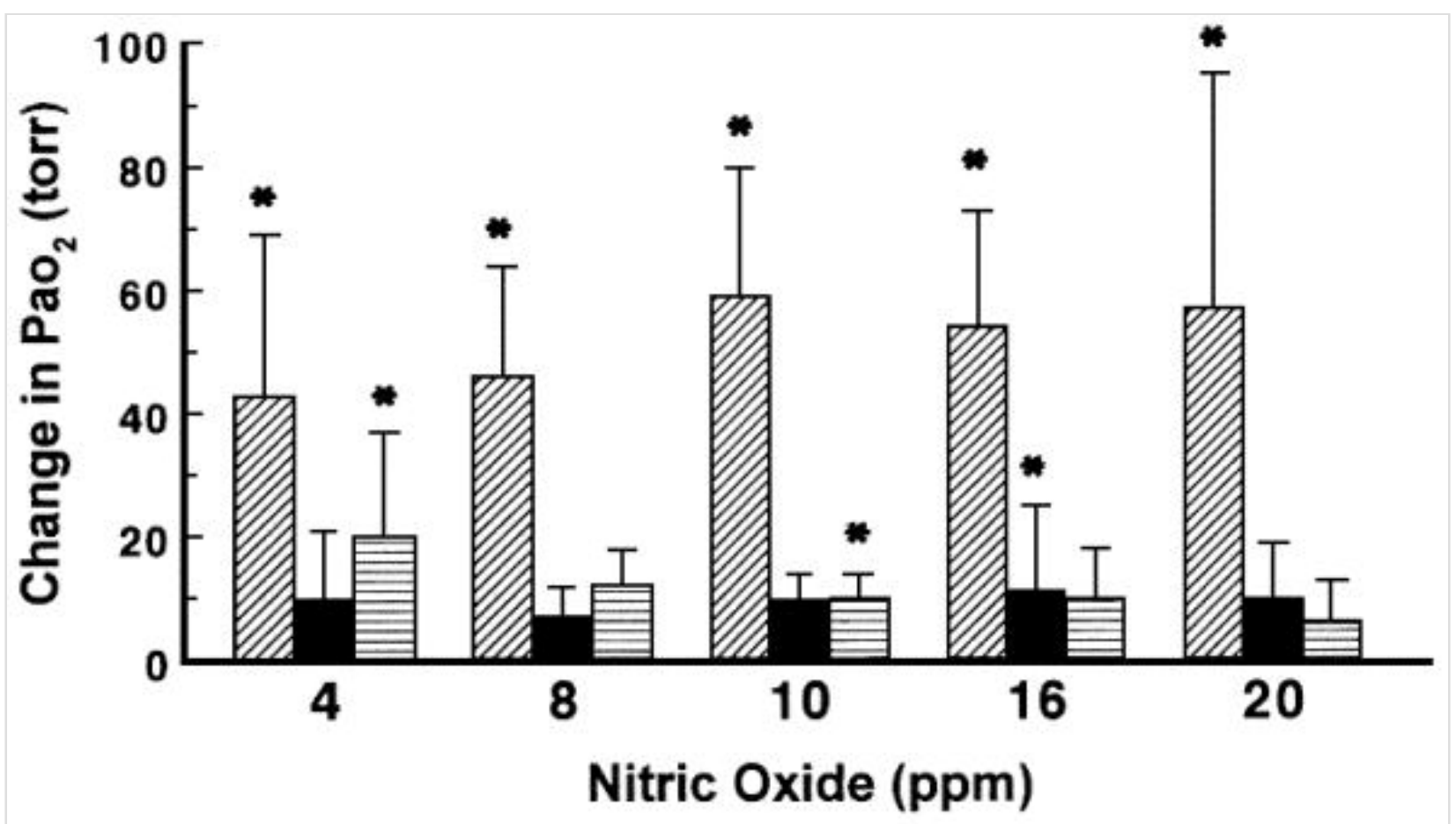

Figure 2. Mean change in $\mathrm{PaO}_{2}$ values (+/- SD) per nitric oxide concentration for the three different groups that inhaled nitric oxide. Diagonal-striped bar, animals $(n=6)$ treated with a low dose of exogenous surfactant $(25$ $\mathrm{mg} / \mathrm{kg}$ ) and inhaled nitric oxide; horizontalstriped bar, animals $(n=6)$ treated with a positive end-expiratory pressure of $10 \mathrm{~cm} \mathrm{H}_{2} \mathrm{O}$ and inhaled nitric oxide; solid bar, animals $(\mathrm{n}=6)$ treated with inhaled nitric oxide alone. *Significant improvement of $\mathrm{PaO}_{2}$ due to inhaled nitric oxide (evaluated with a paired t-test by comparing the mean $\mathrm{PaO}$ sub 2 value when nitric oxide was switched on for 30 mins with the baseline $\mathrm{PaO}_{2}$ value). The baseline blood gas value was defined as the mean $\mathrm{PaO}_{2}$ value of both washout periods, before and after nitric oxide was switched on. ppm, parts per million. To convert torr to $\mathrm{kPa}$, multiply the value by 0.1333 . 
7/26/2016 Ovid: Improved oxygenation by nitric oxide is enhanced by prior lung reaeration with surfactant, rather than positive end-expiratory pressure, in lung- $\ldots$

Mean arterial pressure did not change after nitric oxide inhalation in any of the five groups (Table 1 and Table 3). Methemoglobin concentration remained low $(0.3+/-0.1 \%)$ and there was no increase after nitric oxide inhalation in any of the groups. The expired nitric dioxide concentration was never $>1 \mathrm{ppm}$ during nitric oxide inhalation in any of the groups. The expired nitric dioxide concentrations are given in Table 2.

\begin{tabular}{ccc}
\hline $\begin{array}{c}\text { NO } \\
(\mathrm{ppm})\end{array}$ & $\begin{array}{c}\text { NO Expired } \\
(\mathrm{ppm})\end{array}$ & $\begin{array}{c}\mathrm{NO}_{2} \text { Expired } \\
(\mathrm{ppm})\end{array}$ \\
\hline 4 & $3.7 \pm 0.6$ & $0.25 \pm 0.04$ \\
8 & $7.2 \pm 0.6$ & $0.34 \pm 0.05$ \\
10 & $8.8 \pm 0.8$ & $0.38 \pm 0.06$ \\
16 & $14.3 \pm 0.7$ & $0.60 \pm 0.05$ \\
20 & $17.7 \pm 0.7$ & $0.78 \pm 0.07$ \\
\hline
\end{tabular}

\section{ppm, parts per million.}

Table 2. Expiratory nitric oxide $(\mathrm{NO})$ and nitric dioxide $\left(\mathrm{NO}_{2}\right)$ concentrations measured with an on-line electrochemical sensor (mean $+/-\mathrm{SD}$ )

\section{DISCUSSION}

The application technique limits the pharmacologic effect of nitric oxide to the aerated regions of the lungs [8]. Therefore, progressive atelectasis, as seen in severe RDS or ARDS, decreases effective delivery of this inhalational agent to its site of action in the terminal lung units $[7,9,10]$. This hypothesis was confirmed by the results of the present study, in which inhalation of nitric oxide was less efficacious in improving arterial oxygenation in the control group that received inhaled nitric oxide only, as compared with the group with prior administration of exogenous surfactant (Figure 2). In congenital diaphragmatic hernia lambs,

Karamanoukian et al. [13] reported that the combination of exogenous surfactant and inhaled nitric oxide is beneficial to improving arterial oxygenation. They [13] found that inhalation of $80 \mathrm{ppm}$ of nitric oxide for 10 mins did not improve oxygenation without prior administration of surfactant $(50 \mathrm{mg} / \mathrm{kg})$. From experimental and clinical studies [12,14] in neonatal RDS, it is known that instillation of 100 to $200 \mathrm{mg} / \mathrm{kg}$ of surfactant resulted in recruitment of atelectatic lung regions with maximal improvement of arterial oxygenation. In the present study, we administered a dose of only $25 \mathrm{mg} / \mathrm{kg}$ of surfactant, and the results showed that $\mathrm{PaO}_{2}$ improved to $50 \%$ of the prelavage values within 30 mins and decreased over time due to diminished surfactant function (Figure 1). After treatment of late-stage RDS and ARDS with a low dose of surfactant, transient improvement of $\mathrm{PaO}_{2}$ is attributed to inhibition of the exogenous surfactant by plasma-derived proteins that are filling the alveolar space due to leakage of the alveoli-capillary membrane [14-16]. In addition, in the present study, arterial oxygenation was significantly higher during the whole observation period in the animals that received a combination of surfactant and inhaled nitric oxide, compared with the group that received a low dose $(25 \mathrm{mg} / \mathrm{kg}$ ) of surfactant only (Figure 1). This result may imply that inhaled nitric oxide had a therapeutic effect on the lung injury. In patients with acute lung injury, Benzing and colleagues [17] showed that inhalation of $40 \mathrm{ppm}$ of nitric oxide decreased pulmonary transvascular albumin flux. The exact mechanism is not yet known, but the authors [17] suggested that the decreased pulmonary capillary pressure due to inhaled nitric oxide reduced transvascular filtration. Therefore, we speculate that in our study, inhaled nitric oxide may have decreased the influx of plasma proteins into the alveolar space, and thereby decreased the inhibition of the low dose $(25 \mathrm{mg} / \mathrm{kg})$ of exogenous surfactant, leading to higher $\mathrm{PaO}_{2}$ values in lung-lavaged rabbits. 
7/26/2016 Ovid: Improved oxygenation by nitric oxide is enhanced by prior lung reaeration with surfactant, rather than positive end-expiratory pressure, in lung-...

Other strategies designed to recruit atelectatic lungs, such as increased positive end-expiratory pressure, may be as beneficial as surfactant therapy in the delivery of inhaled nitric oxide to the target cells. In the present study, arterial oxygenation improved after positive end-expiratory pressure was increased from 6 to $10 \mathrm{~cm} \mathrm{H}_{2} \mathrm{O}$ but no additional effect of inhaled nitric oxide was seen on $\mathrm{PaO}$ sub 2 (Figure 1). Furthermore, half of the animals of both positive end-expiratory pressure groups developed a pneumothorax during the observation period, indicating that the peak airway pressures were high (Table 1 and Table 3). From clinical experience, it is known that one of the benefits of surfactant therapy includes lower peak airway pressures with reduced risk of barotrauma [14,16], which is confirmed by the results of this study (Table 1 and Table 3). Putensen et al. [18] demonstrated that in dogs with oleic acid-induced lung injury, adequate recruitment of the lung by a positive end-expiratory pressure of $10 \mathrm{~cm} \mathrm{H}_{2} \mathrm{O}$ was essential to get an increase in oxygenation after inhaled nitric oxide administration compared with a control group without positive endexpiratory pressure. Also, in adult patients with ARDS, Puybasset et al. [7] reported that the effect of nitric oxide on $\mathrm{PaO}_{2}$ was potentiated by the application of $10 \mathrm{~cm} \mathrm{H}$ O positive end-expiratory pressure. This potentiation occurred only in patients in whom positive end-expiratory pressure had induced a significant alveolar recruitment. Thus, it seems realistic to conclude that alveolar recruitment by positive end-expiratory pressure can also improve the efficacy of inhaled nitric oxide. However, we speculate that in the present study, the airway pressures used were too high, leading to high intrathoracic pressures that made vasodilation of the pulmonary vasculature impossible due to inhaled nitric oxide. Therefore, we suggest that alveolar recruitment induced by exogenous surfactant is more beneficial than increased positive endexpiratory pressure for improving arterial oxygenation due to inhaled nitric oxide because of the use of lower airway pressures.

The results of previous clinical observations $[5,6,19,20]$ are controversial concerning the dose-dependency of inhaled nitric oxide. In the present study, there was no dose-dependent effect of the various nitric oxide concentrations used (4 to $20 \mathrm{ppm}$ ) (Figure 2). Most of the animals had a different nitric oxide concentration by which the change in arterial oxygenation was maximal. It appears that each lung has its own "optimal" nitric oxide concentration that probably depends on the severity of the disease process (i.e., atelectasis, edema). In the present study, low doses of nitric oxide ( $<20 \mathrm{ppm}$ ) were used because of the demonstrated efficacy of low doses in animal experiments and in patients, and to minimize toxicity [21]. In the presence of oxygen, nitric oxide is rapidly oxidized to nitrite or nitrates that can induce tissue damage [22]. Also, nitric oxide reacts with superoxide anions to produce peroxynitrite [22]. Haddad and colleagues [23,24] demonstrated in vitro that peroxynitrite inhibits pulmonary surfactant function by lipid peroxidation and damaging surfactant proteins. In the present study, there was no evidence that the surfactant function was more decreased after inhalation of nitric oxide when compared with the control group that only received surfactant (Figure 1). Furthermore, severe methemoglobinemia due to inhalation of nitric oxide has been reported [25]. However, in the present study, no changes in methemoglobin concentrations were observed with the nitric oxide concentrations that were used during the 30-min inhalation periods.

In the present study, we used the lung-lavage model, which has proved to be a consistent and convenient model of acute lung injury [11]. Repeated whole-lung lavage produces an acute quantitative surfactant deficiency. This deficiency, together with conventional mechanical ventilation, leads to severe lung injury with impaired gas exchange, decreased lung compliance and functional residual capacity, increased permeability changes of the alveolicapillary membrane with edema, and sustained pulmonary hypertension $[11,12,26]$. In the present study, animals were first ventilated for 45 mins after the last lavage before treatment was started to induce a more severe lung injury. Although an untreated control group was not used in this study, we [27] have previously demonstrated with the same model that after the lavage procedure, there is no spontaneous improvement in oxygenation or lung mechanics over a 6-hr period. Despite the fact that the lung injury in this study is not representative of the pathology seen in humans with ARDS, this model is ideal for testing interventions that may prove therapeutic for acute lung injury [12,2732]. 
7/26/2016 Ovid: Improved oxygenation by nitric oxide is enhanced by prior lung reaeration with surfactant, rather than positive end-expiratory pressure, in lung-...

We conclude that in lung-lavaged rabbits, the effect of nitric oxide on improving oxygenation is superior when lung aeration is increased with exogenous surfactant rather than with positive end-expiratory pressure. In neonates with RDS and patients with ARDS, it has been shown that both exogenous surfactant and nitric oxide increase $\mathrm{PaO}_{2}$ by improving the ventilation/perfusion match $[2-6,14,16]$. Whereas the inhalation of nitric oxide improves perfusion of the ventilated areas of the lung, instillation of exogenous surfactant leads to improvement of the ventilation by reaeration of the atelectatic regions. Therefore, combined therapy of exogenous surfactant and nitric oxide inhalation could be clinically important, especially in patients with ARDS. Nevertheless, in terms of our goal of improving oxygenation while diminishing lung injury, it remains unclear whether a low dose of surfactant plus inhaled nitric oxide is more optimal than a high dose of surfactant.

\section{ACKNOWLEDGMENTS}

We thank Ms. Laraine Visser-Isles for the English language editing and Ari Kok for expert technical assistance.

\section{REFERENCES}

1. Palmer RMJ, Ferrige AG, Moncada S: Nitric oxide release accounts for the biological activity of endothelium-derived relaxing factor. Nature 1987; 327:524-526 Full Text @ EUR | Bibliographic Links [Context Link]

2. Roberts JD, Polaner DM, Lang $P$, et al: Inhaled nitric oxide in persistent pulmonary hypertension of the newborn. Lancet 1992; 340:818-819 Full Text @ EUR | Full Text | Bibliographic Links |[Context Link]

3. Kinsella JP, Neish SR, Shaffer E, et al: Low-dose inhalational nitric oxide in persistent pulmonary hypertension of the newborn. Lancet 1992; 340:819-820 Full Text @ EUR | Full Text | Bibliographic Links | [Context Link]

4. Rossaint R, Falke KJ, Lopez F, et al: Inhaled nitric oxide for the adult respiratory distress syndrome. N Engl J Med 1993; 328:399-405 Full Text @ EUR | Bibliographic Links | [Context Link]

5. Gerlach H, Rossaint R, Pappert D, et al: Time-course and dose-response of nitric oxide inhalation for systemic oxygenation and pulmonary hypertension in patients with adult respiratory distress syndrome. Eur $\mathrm{J}$ Clin Invest 1993; 23:499-502 Full Text @ EUR | Bibliographic Links | [Context Link]

6. Bigatello LM, Hurford WE, Kacmarek RM, et al: Prolonged inhalation of low concentrations of nitric oxide in patients with severe adult respiratory distress syndrome. Anesthesiology 1994; 80:761-770 Ovid Full Text | Full Text @ EUR | Bibliographic Links |[Context Link]

7. Puybasset L, Rouby J-J, Mourgeon E, et al: Factors influencing cardiopulmonary effects of inhaled nitric oxide in acute respiratory failure. Am J Respir Crit Care Med 1995; 152:318-328 Full Text @ EUR Bibliographic Links | [Context Link]

8. Gaston B, Drazen JM, Loscalzo J, et al: The biology of nitrogen oxides in the airways. Am J Respir Crit Care Med 1994; 149:538-551 Full Text @ EUR | Bibliographic Links | [Context Link]

9. Kinsella JP, Abman SH: Efficacy of inhalational nitric oxide therapy in the clinical management of persistent pulmonary hypertension of the newborn. Chest 1994; 105:92S-94S Full Text @ EUR Bibliographic Links | [Context Link]

10. Wilcox DT, Glick PL, Karamanoukian HL, et al: Perfluorocarbon-associated gas exchange improves pulmonary mechanics, oxygenation, ventilation, and allows nitric oxide delivery in the hypoplastic lung 
7/26/2016 Ovid: Improved oxygenation by nitric oxide is enhanced by prior lung reaeration with surfactant, rather than positive end-expiratory pressure, in lung-... congenital diaphragmatic hernia lamb model. Crit Care Med 1995; 23:1858-1863 [Context Link]

11. Lachmann B, Robertson B, Vogel J: In vivo lung lavage as an experimental model of the respiratory distress syndrome. Acta Anaesthesiol Scand 1980; 24:231-236 Full Text @ EUR | Bibliographic Links [Context Link]

12. Gommers D, Vilstrup C, Bos JAH, et al: Exogenous surfactant therapy increases static lung compliance, and cannot be assessed by measurement of dynamic compliance alone. Crit Care Med 1993; 21:567-574 [Context Link]

13. Karamanoukian HL, Glick PL, Wilcox DT, et al: Pathophysiology of congenital diaphragmatic hernia VIII: Inhaled nitric oxide requires exogenous surfactant therapy in the lamb model of congenital diaphragmatic hernia. J Pediatr Surg 1995; 30:1-4 Full Text @ EUR | Bibliographic Links | [Context Link]

\section{Jobe AH: Pulmonary surfactant therapy. N Engl J Med 1993; 328:861-868 Full Text @ EUR Bibliographic Links | [Context Link]}

15. Lachmann B, Eijking EP, So KL, et al: In vivo evaluation of the inhibitory capacity of human plasma on exogenous surfactant function. Intensive Care Med 1994; 20:6-11 Full Text @ EUR | Bibliographic Links | [Context Link]

16. Gommers D, Lachmann B: Surfactant therapy perspectives in adult patients. Curr Opin Crit Care 1995; 1:57-61 [Context Link]

17. Benzing A, Brautigam P, Geiger K, et al: Inhaled nitric oxide reduces pulmonary transvascular albumin flux in patients with acute lung injury. Anesthesiology 1995; 83:1153-1161 Ovid Full Text | Full Text @ EUR | Bibliographic Links | [Context Link]

18. Putensen C, Rasanen J, Lopez FA, et al: Continuous positive airway pressure modulates effect of inhaled nitric oxide on the ventilation/perfusion distributions in canine lung injury. Chest 1994; 106:15631569 Full Text @ EUR | Bibliographic Links | [Context Link]

19. Finer NN, Etches PC, Kamstra B, et al: Inhaled nitric oxide in infants referred for extracorporeal membrane oxygenation: Dose response. J Pediatr 1994; 124:302-308 Full Text @ EUR | Full Text Bibliographic Links | [Context Link]

20. Day RW, Guarin M, Lynch JM, et al: Inhaled nitric oxide in children with severe lung disease: Results of acute and prolonged therapy with two concentrations. Crit Care Med 1996; 24:215-221 Ovid Full Text Full Text @ EUR | Bibliographic Links | [Context Link]

21. Foubert L, Fleming B, Latimer R, et al: Safety guidelines for use of nitric oxide. Lancet 1992; 339:16151616 Full Text @ EUR | Full Text | Bibliographic Links $\mid$ [Context Link]

22. Moncada S, Higgs A: The L-argininenitric oxide pathway. N Engl J Med 1993; 329:2002-2012 [Context Link]

23. Haddad IY, Ischiropoulos H, Holm BA, et al: Mechanisms of peroxynitrite-induced injury to pulmonary surfactants. Am J Physiol 1993; 265:L555-L564 Full Text @ EUR | Bibliographic Links | [Context Link]

24. Haddad IY, Crow JP, Hu P, et al: Concurrent generation of nitric oxide and superoxide damages surfactant protein A. Am J Physiol 1994; 267:L242-L249 Full Text @ EUR | Bibliographic Links |[Context 
7/26/2016 Ovid: Improved oxygenation by nitric oxide is enhanced by prior lung reaeration with surfactant, rather than positive end-expiratory pressure, in lung-... Link]

25. Young JD, Dyar O, Xiong L, et al: Methaemoglobin production in normal adults inhaling low concentrations of nitric oxide. Intensive Care Med 1994; 20:581-584 Full Text @ EUR | Bibliographic Links | [Context Link]

26. Burger R, Bryan AC: Pulmonary hypertension after postlavage lung injury in rabbits: Possible role of polymorphonuclear leukocytes. J Appl Physiol 1991; 71:1990-1995 Full Text @ EUR| Bibliographic Links [Context Link]

27. Tutuncu AS, Akpir K, Mulder P, et al: Intratracheal perfluorocarbon administration as an aid in the ventilatory management of respiratory distress syndrome. Anesthesiology 1993; 79:1083-1093 Ovid Full Text | Full Text @ EUR | Bibliographic Links | [Context Link]

28. Rovira I, Chen TY, Winkler M, et al: Effects of inhaled nitric oxide on pulmonary hemodynamics and gas exchange in an ovine model of ARDS. J Appl Physiol 1994; 76:345-355 [Context Link]

29. Lewis JF, Tabor B, Ikegami M, et al: Lung function and surfactant distribution in saline-lavaged sheep given instilled vs. nebulized surfactant. J Appl Physiol 1993; 74:1256-1264 [Context Link]

30. Segerer H, van Gelder W, Angenent FWM, et al: Pulmonary distribution and efficacy of exogenous surfactant in lung-lavaged rabbits are influenced by the instillation technique. Pediatr Res 1993; 34:490-494 Ovid Full Text | Full Text @ EUR | Bibliographic Links | [Context Link]

31. Tutuncu AS, Faithfull NS, Lachmann B: Intratracheal perfluorocarbon administration combined with mechanical ventilation in experimental respiratory distress syndrome: Dose-dependent improvement of gas exchange. Crit Care Med 1993; 21:962-969 Ovid Full Text | Full Text @ EUR | Bibliographic Links [Context Link]

32. Lachmann B, Jonson B, Lindroth $\mathrm{M}$, et al: Mode of artificial ventilation in severe respiratory distress syndrome. Lung function and morphology in rabbits after wash-out of alveolar surfactant. Crit Care Med 1982; 10:724-732 Ovid Full Text | Full Text @ EUR | Bibliographic Links | [Context Link]

\section{IMAGE GALLERY}

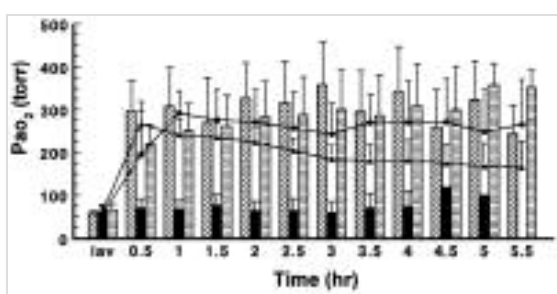

Figure 1

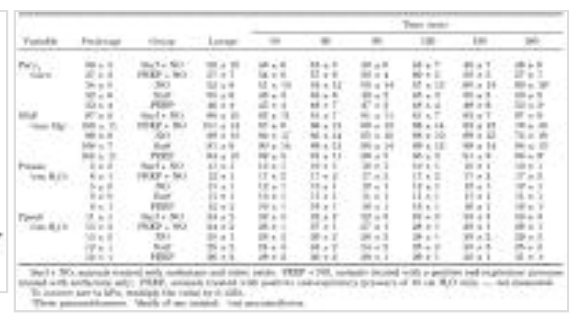

Table 1

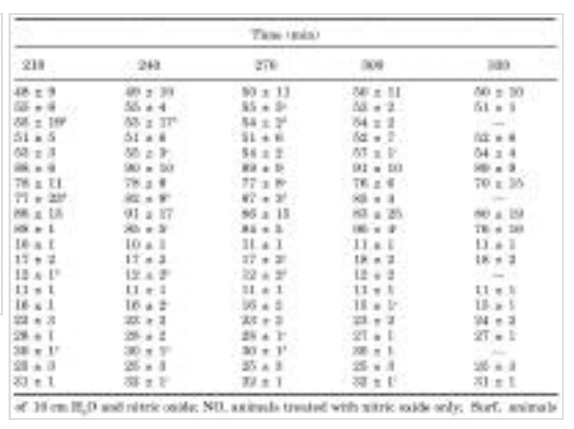

Table 3 
7/26/2016 Ovid: Improved oxygenation by nitric oxide is enhanced by prior lung reaeration with surfactant, rather than positive end-expiratory pressure, in lung- $\ldots$

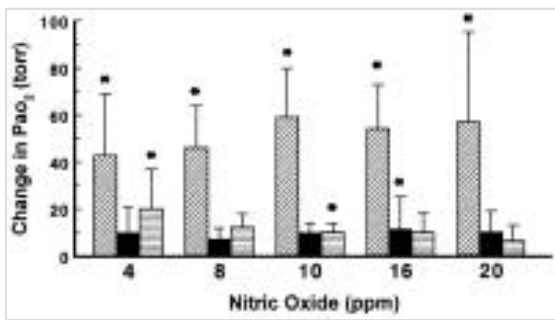

Figure 2

\begin{tabular}{ccc}
\hline $\begin{array}{c}\text { NO } \\
(\mathrm{ppm})\end{array}$ & $\begin{array}{c}\text { NO Expired } \\
(\mathrm{ppm})\end{array}$ & $\begin{array}{c}\mathrm{NO}_{2} \text { Expired } \\
(\mathrm{ppm})\end{array}$ \\
\hline 4 & $3.7 \pm 0.6$ & $0.25 \pm 0.04$ \\
8 & $7.2 \pm 0.6$ & $0.34 \pm 0.05$ \\
10 & $8.8 \pm 0.8$ & $0.38 \pm 0.06$ \\
16 & $14.3 \pm 0.7$ & $0.60 \pm 0.05$ \\
20 & $17.7 \pm 0.7$ & $0.78 \pm 0.07$ \\
\hline \multicolumn{3}{c}{ ppm, parts per million. } \\
\hline
\end{tabular}

Table 2

Back to Top

(c) 2016 Ovid Technologies, Inc. All rights reserved.

\begin{tabular}{l|l|l} 
About Us & Contact Us & Terms of Use
\end{tabular}

OvidSP_UI03.20.00.112, SourceID 105955 